\title{
Vertical and longitudinal variations in plant communities of drawdown zone of a monsoonal riverine reservoir in South Korea
}

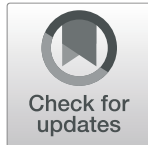

Hyunsuk Cho ${ }^{1,4}$, Rob H. Marrs ${ }^{2}$, Josu G. Alday ${ }^{3}$ and Kang-Hyun Cho ${ }^{1 *}$

\begin{abstract}
Background: The plant communities within reservoir drawdown zones are ecologically important as they provide a range of ecosystem services such as stabilizing the shoreline, improving water quality, enhancing biodiversity, and mitigating climate change. The aim of the study was therefore to identify the major environmental factors affecting these plant communities within the drawdown zone of the Soyangho Reservoir in South Korea, which experiences a monsoonal climate, and thereafter to (1) elucidate the plant species responses and (2) compare the soil seedbank composition along main environmental gradients.

Results: Two main environmental gradients affecting the plant community structure were identified within the drawdown zone; these were a vertical and longitudinal gradient. On the vertical dimension, a hydrological gradient of flood/exposure, the annual-dominated plant community near the water edge changed to a perennial-dominated community at the highest elevation. On the longitudinal dimension from the dam to the upstream, plant species composition changed from an upland forest-edge community to a lowland riverine community, and this was correlated with slope degree, soil particle size, and soil moisture content. Simultaneously, the composition of the soil seedbank was separated along the vertical gradient of the drawdown zone, with mainly annuals near the water edge and some perennials at higher elevations. The species composition similarity between the seedbank and extant vegetation was greater in the annual communities at low elevation than in the perennial communities at higher elevation.

Conclusions: The structures of plant community and soil seedbank in the drawdown zone of a monsoonal riverine reservoir were changed first along the vertical and secondly along the longitudinal gradients. The soil seedbank could play an important role on the vegetation regeneration after the disturbances of flood/exposure in the drawdown zone. These results indicate that it is important to understand the vertical and longitudinal environmental gradients affecting shoreline plant community structure and the role of soil seedbanks on the rapid vegetation regeneration for conserving and restoring the drawdown zone of a monsoonal reservoir.
\end{abstract}

Keywords: Elevation, Environmental gradient, Geomorphology, Soil seedbank, Soyangho Reservoir, Vascular plants

\section{Background}

Most water reservoirs are formed by placing a dam across a river, and hence they show characteristics intermediate between a river and a natural lake (Thornton 1990), with riverine and dendritic forms created as a result of the artificial inundation of the former riverine floodplain. In such reservoirs, the physical, chemical,

\footnotetext{
* Correspondence: khcho@inha.ac.kr

${ }^{1}$ Department of Biological Sciences, Inha University, Incheon 22212, Republic of Korea

Full list of author information is available at the end of the article
}

and biological characteristics change along two main spatial dimensions; (1) the longitudinal dimensionchanging through fluvial, transitional, and lacustrine zones along the main reservoir axis from the inflow to the dam (Kimmel and Groeger 1984), and (2) the vertical dimension-changing from aquatic communities at the bottom near the through water body, through the shoreline/drawdown zone, to the upper areas. Along the longitudinal gradient, basin morphology, flow velocity, and other related environments such as suspended particles, nutrients, etc. are expected to change (Kimmel and 
Groeger 1984). On the other hand, conditions related to water depth in the aquatic zone (Wetzel 2001) and conditions related to water level fluctuation within in the drawdown zone change along the vertical gradient of reservoirs (Baxter 1977).

The water level of the reservoir can fluctuate widely because it is manipulated by management for operational objectives (e.g., flood control, irrigation, or domestic water supply) as well as responding to natural hydrological process (Zohary and Ostrovsky 2011). In a reservoir with large fluctuations, the area defined as the drawdown zone forms between the area of land at the edge of a water body where exposure-flood cycle occurs through changing water levels (Abrahams 2005). Within this drawdown zone a distinctive flora is found that is adapted to these rapidly changing environments (Hill et al. 1998; Abrahams 2005). The plant communities of the drawdown zone could be expected to be affected by exposure/flood cycles along the vertical gradient (e.g., Nilsson and Keddy 1988; Bao et al. 2015) as well as by the environmental changes along the longitudinal gradient in riverine reservoirs. Regeneration of this vegetation from the soil seedbank is likely to be important along these gradients, especially in areas with frequent and intense disturbance of exposure/ flooding (Zhang et al. 2016). However, information regarding the effects of both vertical and longitudinal gradients on the plant communities within the drawdown zone is severely limited, especially for those reservoirs of riverine and dendritic shape with wide water level fluctuations. This is likely to occur where there is a monsoonal climate. The Soyangho Reservoir is one such reservoir; it is the largest in South Korea with a water surface area of $70 \mathrm{~km}^{2}$ (Kim et al. 2000), and it has a dendritic and riverine morphology due to its location in a mountainous area. Moreover, a large drawdown zone has been formed due to a very wide annual range of water level fluctuation with a maximum of $37 \mathrm{~m}$ between 1974 and 2017 (Han River Flood Control Office 2018 ).

The specific objectives of the study were therefore to elucidate the relationship between the vegetation structure and environmental factors along both the vertical and horizontal gradients: (1) to identify the important environmental factors affecting plant community structure, (2) to elucidate the responses of plant species along the major environmental gradients, and (3) to compare species composition of soil seedbanks under a contrasting plant communities.

\section{Materials and methods \\ Study area}

The plant community structure of the drawdown zone was investigated in the Soyangho Reservoir ( $37^{\circ} 56^{\prime} 44^{\prime \prime}$ $\mathrm{N}, 127^{\circ} 48^{\prime} 52^{\prime \prime} \mathrm{E}$ ), which is located in a mountainous area of the Hangang River watershed in South Korea
(Fig. 1). This reservoir was constructed in 1973 to produce multiple benefits, e.g., flood prevention, water supply, hydro-electric power generation, and for recreational use. It was impounded within deep canyons with the main channel being $60-\mathrm{km}$ long and with a mean width of 0.5 $\mathrm{km}$ (Kim and Kim 2006). Along this main channel, there are many branches forming a dendritic shape, with the branches extending up submerged valleys up to $5 \mathrm{~km}$ from the main axis (Kim et al. 2000; Kim and Lee 2017). The mean water depth is $34 \mathrm{~m}$, with a maximum water depth of $118 \mathrm{~m}$ (Kim and Kim 2006).

The rainfall within the watershed of the Hangang River is concentrated in a few episodic heavy showers of over $100 \mathrm{~mm} /$ day during the monsoonal season with more than half of the annual precipitation $(1347 \mathrm{~mm})$ falling in July and August (Weather Station Inje; Korea Meteorological Administration 2018). The reservoir water level is often lowered during the dry season to allow monsoonal inflow and increased to a maximum level during the monsoon season (Fig. 2a). Annual water level fluctuations are therefore very wide with a mean of $24.5 \mathrm{~m}$ recorded between 2006 and 2015 (Han River Flood Control Office 2018). These wide water level fluctuations produce a large drawdown zone along the shorelines with annual cycles of submergence and exposure. As the elevations increase from the lowest to the highest water level, exposure durations increased (Fig. $2 b)$. The slopes of the drawdown close to the dam main are very steep, often with exposed bare rock with no or rare vegetation. However, in the upstream areas distant from the dam and especially near stream inflows, the slopes are gentler and shoreline vegetation becomes established (Table 1 and Additional file 1: Figure S1).

\section{Field survey}

We surveyed plant communities in the drawdown zone at nine sites within the reservoir in May and June 2010 (Fig. 1 and Table 1); survey sites S1 to S4 were distant from the dam and sites S5 to S9 were closer. At each survey site, one to three transects according to the community diversity of the site were established through the drawdown zone to assess the change in plant communities through the elevational gradient. As all communities were dominated by herbaceous species $2 \mathrm{~m} \times 2 \mathrm{~m}$ quadrats were used; they were established in every physiognomicallydifferent plant community detected along a transect. The total number of the quadrats was 84 along the total 12 transects in this survey. Both floristic composition and species cover were measured at each quadrat, the latter using a 12-point cover scale with $10 \%$ cover-classes and two classes for species with $<5 \%$ cover (Additional file 1 : Table S1a). The nomenclature of vascular plant species follows the Korean Plant Names Index (Korea National Arboretum 2017). 


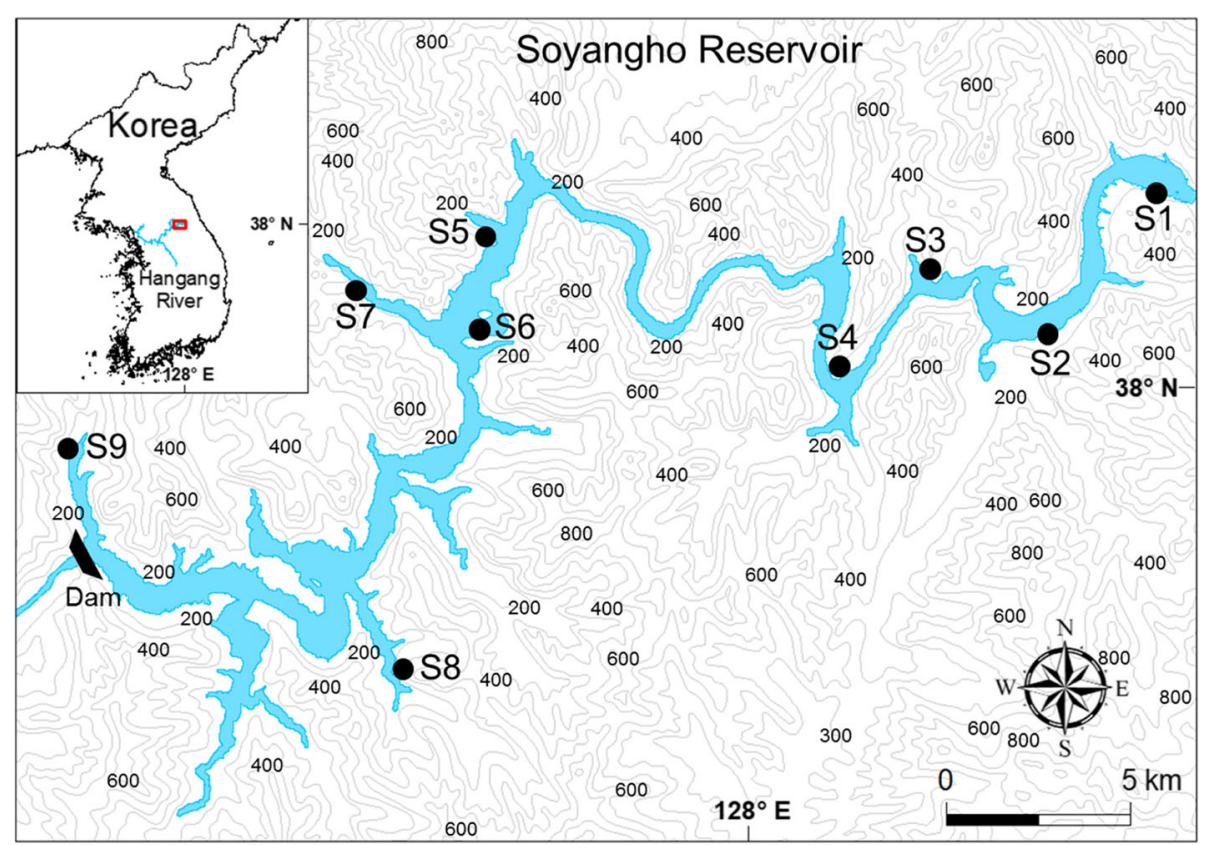

Fig. 1 Location of the Soyangho Reservoir in South Korea indicating the sampling sites (closed circles); the numerals on the contour lines indicate elevation above sea level ( $m$ a.s.l.)

At the same time, environmental variables were measured for each sampled quadrat, i.e., distance from the dam, elevation, exposure duration, aspect and angle of slope, and texture and moisture contents of soils. The distance from the dam to the survey site was measured along the water channel on a 1:25,000 map (Korea Geographic Information Institute 2010). The aspect of slope was measured using a compass, and elevation and slope degree were surveyed using a ProMark 700 Global Navigation Satellite System (GNSS) receiver (Spectra Precision, USA) or an automatic level (Jogger 24, Leica Geosystems, Switzerland) and a measuring tape along the established line transects. The elevation above sea level (a.s.l.) of the quadrat was calculated from the relative elevation above the daily water level which was reported by Han River Flood Control Office (2018). The angle of the slope for each community was calculated using distance and elevation measurements and Euclidean geometry. Annual exposure duration for each quadrat was calculated from the elevation using their regression equation fitted by daily water level data from 2006 to 2015 (Fig. 2b). Soil texture was evaluated using field assessment methods (Japanese Society of Pedology 1997; Additional file 1: Table S1b) and soil moisture on a 3 -point scale $(1=$ Dry, $2=$ Moist, $3=$ Wet $)$.

\section{Soil seedbank survey}

We selected six plant communities for comparing the soil seedbanks between the communities dominated by plants with different life histories and at the different elevations; three dominated by annuals at lower elevations of the drawdown zone (Bidens frondosa, Persicaria nodosa, Persicaria trigonocarpa) and here dominated by perennials at higher elevations (Carex orbicularis var. brachylepis, Phalaris arundinacea, Scirpus radicans). At the end of March 2011, six quadrats $(1 \mathrm{~m} \times 1 \mathrm{~m})$ were located randomly within each plant community within the drawdown zone. At each quadrat, five soil cores (diameter $5 \mathrm{~cm}$ and depth $5 \mathrm{~cm}$ ) were sampled randomly. The samples from each quadrat were bulked and mixed thoroughly, and a sample (20\% by weight) was sub-sampled for the seedbank analysis.

The soil seedbank was analyzed by measuring direct seedling emergence (Lee et al. 2014). The six bulked soil samples of each plant community were sprinkled onto the surface of a germination tray $(250 \mathrm{~mm} \times 380 \mathrm{~mm} \times$ $80 \mathrm{~mm}$ deep) filled with $3-\mathrm{cm}$ sterile potting compost. The germination trays were maintained in a glasshouse from April 2013 for 108 days with daily watering. The positions of the trays were changed randomly every 2 weeks. All identifiable seedlings were counted and then removed to prevent overcrowding after 19, 49, 75, and 108 days. Seedlings that were difficult to identify were transplanted to separate pots and allowed to grow until identification was possible.

\section{Data analysis}

All statistical analyses were performed within the $\mathrm{R}$ statistical environment ( $R$ version 3.4.0; $R$ Core Team 2017) using the "vegan" package (Oksanen et al. 2016) and the 
(a) Water level

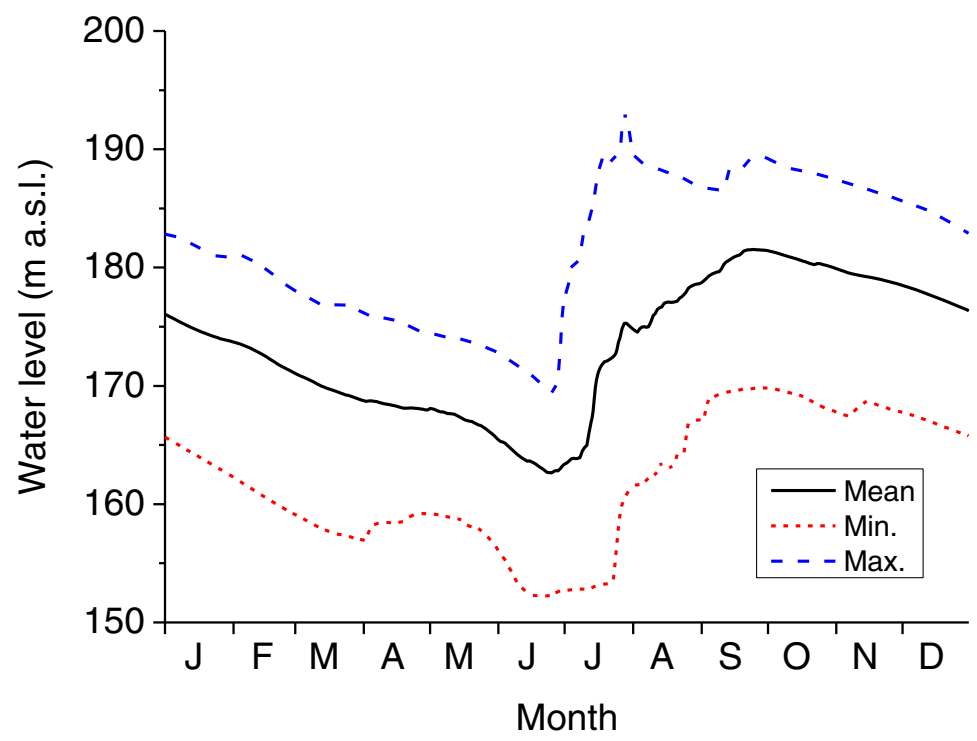

(b) Exposure duration

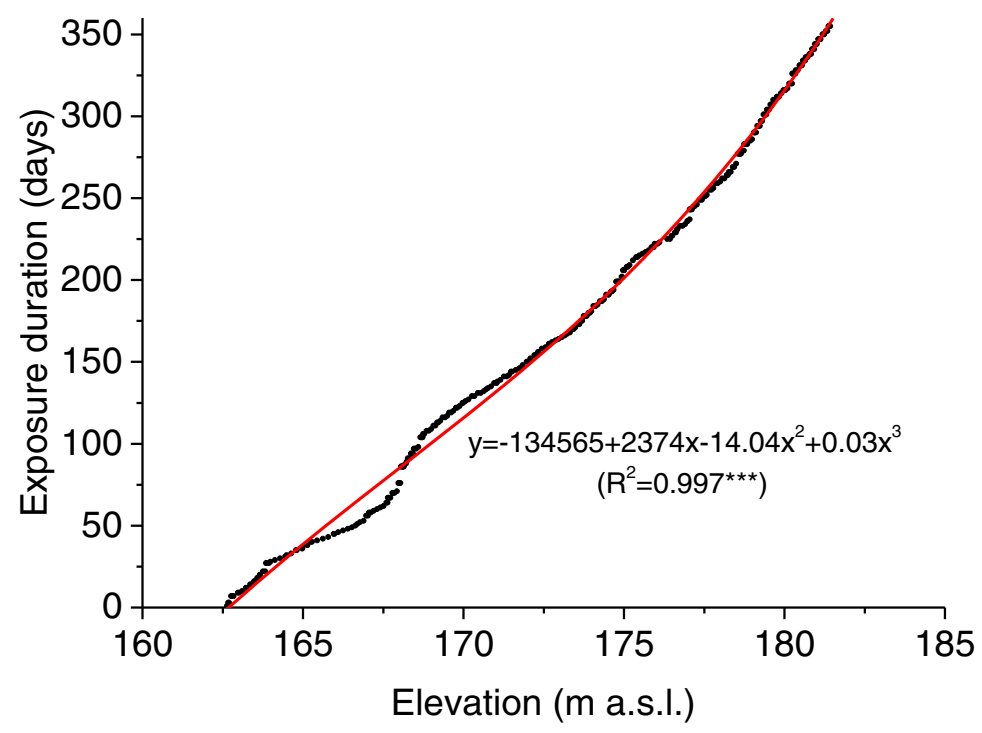

Fig. 2 Seasonal changes in mean, maximum, and minimum of the water level above sea level (a) and annual mean exposure duration with elevation above sea level (a.s.l.) (b) from 2006 to 2015 in the Soyangho Reservoir (data from Han River Flood Control Office 2018)

"eHOF" package (Jansen and Oksanen 2017). First, to visualize the relationships between the sampling sites of plant communities and their environmental factors, principal components analysis (PCA) was performed with the "rda" function. Second, canonical correspondence analysis (CCA) was used to provide an integrated analysis of the relationship between plant community structure and measured environmental variables; the vegetation data matrix was transformed $\left(\log _{\mathrm{e}}(X+1)\right.$, where $X=$ vegetation cover) after removing species that were present in only one sample. The constraining variables (i.e., distance from the dam, elevation, exposure duration, slope angle, soil texture, and soil moisture) were included in the CCA model using stepwise selection based on the AIC (Akaike information criterion) statistic as the selection criterion (Oksanen 2015), with significance assessed using 200 permutations. Standard 
Table 1 Location, distance to the dam, slope aspect, and mean slope degree (range in parenthesis) of the drawdown zone within the study sites of the Soyangho Reservoir, South Korea

\begin{tabular}{llllll}
\hline Site & Latitude $\left({ }^{\circ} \mathrm{N}\right)$ & Longitude $\left(^{\circ} \mathrm{E}\right)$ & Distance from the dam $(\mathrm{km})$ & Slope aspect $\left({ }^{\circ} \mathrm{N}\right)$ & Slope angle $\left(^{\circ}\right)$ \\
\hline S1 & $38^{\circ} 02^{\prime} 18.2^{\prime \prime}$ & $128^{\circ} 09^{\prime} 11.5^{\prime \prime}$ & 56 & 40 & $3(0-13)$ \\
S2 & $38^{\circ} 00^{\prime} 08.7^{\prime \prime}$ & $128^{\circ} 06^{\prime} 59.1^{\prime \prime}$ & 49 & 300 & $9(3-14)$ \\
S3 & $38^{\circ} 00^{\prime} 58.2^{\prime \prime}$ & $128^{\circ} 04^{\prime} 41.1^{\prime \prime}$ & 44 & 120 & $4(1-21)$ \\
S4 & $37^{\circ} 59^{\prime} 21.7^{\prime \prime}$ & $128^{\circ} 03^{\prime} 04.0^{\prime \prime}$ & 40 & 140 & $6(2-20)$ \\
S5 & $38^{\circ} 01^{\prime} 22.2^{\prime \prime}$ & $127^{\circ} 56^{\prime} 29.7^{\prime \prime}$ & 22 & 320 & $16(4-18)$ \\
S6 & $38^{\circ} 00^{\prime} 01.8^{\prime \prime}$ & $127^{\circ} 56^{\prime} 26.7^{\prime \prime}$ & 14 & 50 & $13(2-18)$ \\
S7 & $38^{\circ} 01^{\prime} 01.9^{\prime \prime}$ & $127^{\circ} 53^{\prime} 36.4^{\prime \prime}$ & 15 & 290 & $6(1-40)$ \\
S8 & $37^{\circ} 56^{\prime} 29.9^{\prime \prime}$ & $127^{\circ} 56^{\prime} 15.5^{\prime \prime}$ & 13 & 140 & $16(3-45)$ \\
S9 & $37^{\circ} 58^{\prime} 36.8^{\prime \prime}$ & $127^{\circ} 48^{\prime} 59.0^{\prime \prime}$ & 4 & & $21(11-49)$ \\
\hline
\end{tabular}

deviational ellipses (95\% confidence limits) were used to illustrate the sampling sites in the biplot (Oksanen et al. 2016). We also used the "ordisurf" function to contour elevation and distance from the dam latitude in the biplot. Third, the response of major species along the gradients of elevation and distance from the dam were characterized using a Huisman-Olff-Fresco (HOF) model (Huisman et al. 1993) with the square root transformation of their cover data. Total 12 species were selected for this analysis based on frequencies (more than 9 quadrats) and total coverages (above 100\%) in the 84 sampled quadrats. The best fit of unimodal model was chosen to obtain reliable species response curve when the bimodal response curve was selected in the HOF model. Fourth, detrended correspondence analysis (DCA) was performed to visualize the relationships of the soil seedbank structure using the "decorana" functions (Oksanen et al. 2016). Numbers of seedlings from the seedling emergence experiment were transformed $\left(\log _{\mathrm{e}}(X+1)\right)$ before analysis, removing species that were present in only one sample. The "ordiellipse" function was then used to indicate the distribution range (95\% confidence intervals) of plots within each community dominated by plants with different life histories. Afterwards, permutational multivariate analysis of variance (PMAV) using Euclidean distance was used to examine and quantify the differences in seedbank structures between community types (annual and perennial-dominated communities). Finally, the relationship in floristic composition between soil seedbank and above-ground vegetation was analyzed using Sorensen's similarity index using presence/ absence data (Magurran 1988). The difference in the seedbank composition and the similarity indices were tested by $t$ test between the annual and perennial plant communities.

\section{Results}

Plant community structure in relation to environmental factors

The PCA results for the six environmental variables revealed two main axes that together explained $72 \%$ the total variation (Fig. 3). Two main environmental gradients were detected from the biplot of environmental variables: (1) elevation and its related exposure duration and (2) distance from the dam and its related angle of slope, soil particle size, and moisture content (Fig. 3a). The sites located some distance from the dam were placed mainly on the upper right side and the closest sites were located on the lower left side of the site biplot (Fig. 3b).

In the CCA of the drawdown zone vegetation (Fig. 4), the species biplot showed a gradation from perennials (e.g., C. orbicularis var. brachylepis, Equisetum arvense, P. arundinacea, Pteridium aquilinum var. latiusculum) located mainly at the negative end of Axis 1 through to annuals (e.g., P. nodosa, P. trigonocarpa, B. frondosa, Panicum dichotomiflorum) positioned around the center through to the positive end of Axis 1 (Fig. 4a, b). The quadrats were located along a gradient parallel to Axis 2 (Fig. 4c) with those closest to the dam (e.g., S8, S9) located at the negative end and those distant from the dam (e.g., S1, S2) at the positive end. The significant environmental variables produced two orthogonal gradients (Fig. 4d). The first gradient, the elevation of the drawdown zone was correlated negatively with Axis 1, suggesting that on slopes, there was a greater abundance of perennials at the top of the gradient with annuals at the bottom. The second gradient, distance from the dam, was correlated with Axis 2. Along this gradient forest-edge plants such as $P$. aquilinum var. latiusculum and Stellaria aquatica were associated close to the dam, whereas steam-bar or floodplain plants such as C. orbicularis var. brachylepis and Rumex crispus were found at the more distant sites.

\section{Plant species responses to environmental gradients}

The 12 most common species showed sequential responses to elevation (Fig. 5). Three annual species (Echinochloa crus-galli, P. nodosa and Bidens radiata var. pinnatifida) were found in greater abundance at low elevation, and two perennial species ( $P$. arundinacea and $E$. 


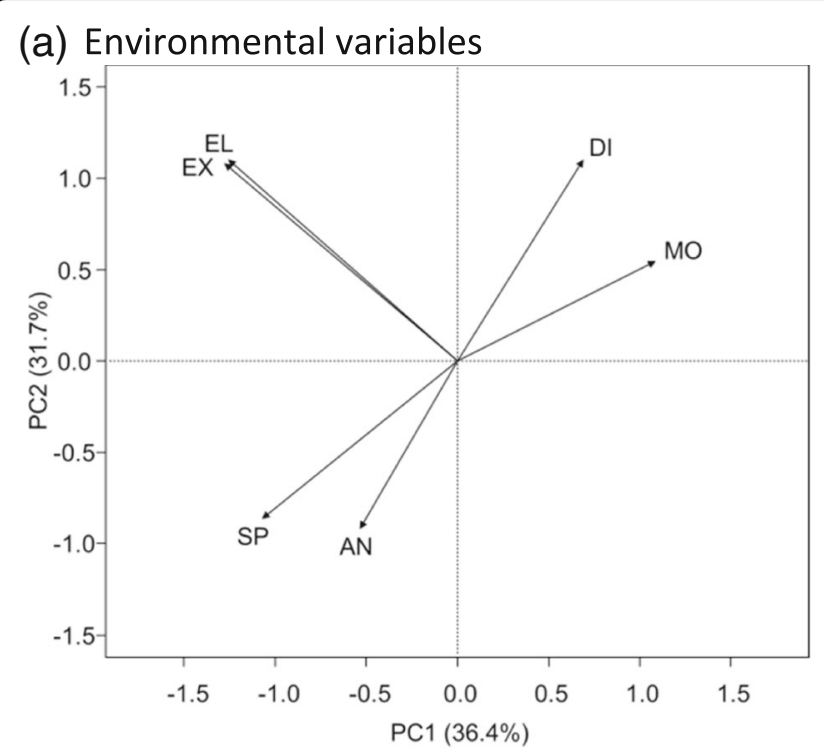

(b) Site plot

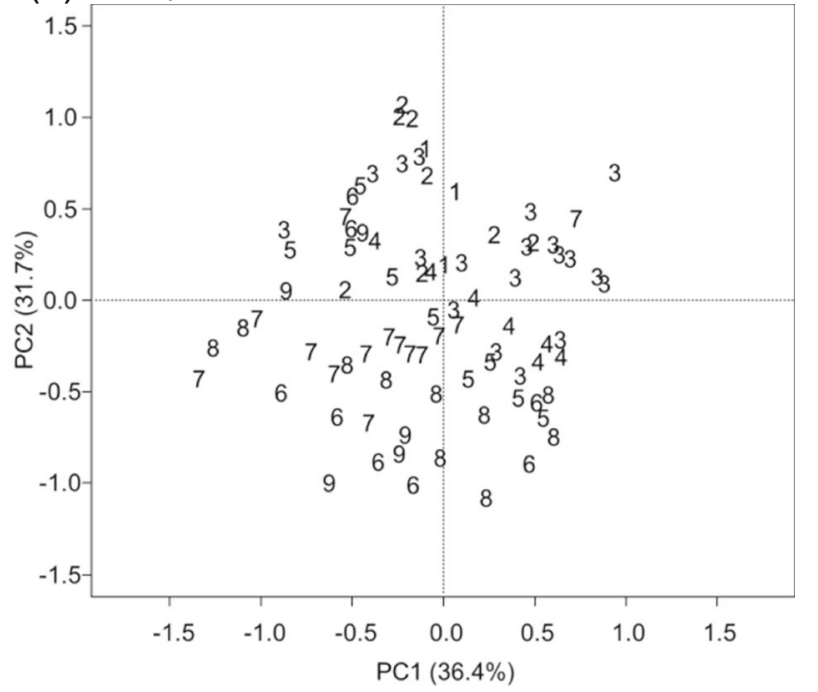

Fig. 3 Biplots from the principal component analysis (PCA) of the environments in the drawdown zone of the Soyangho Reservoir, South Korea. a Plot of environmental variables (AN, slope angle; EL, elevation; EX, exposure duration; DI, distance from the dam; MO, soil moisture SP, soil particle size) and (b) site plot (numeral relates to the sampling site in the Fig. 1 and same numerals mean the quadrats along the transect in each site)

arvense) were most abundant at high elevation. The other five annuals (Sagina japonica, B. frondosa, P. trigonocarpa, Setaria viridis, Matricaria chamomilla and Ambrosia artemisiifolia) and one perennial (Calystegia hederacea) peaked at mid-elevation. Four eHOF models were identified with respect to plant species response to the elevation (Fig. 5). The species responses to distance from the dam could not be clearly explained by eHOF models (Additional file 1: Figure S2).

\section{Response of soil seedbank to the elevation in the drawdown zone}

Eighteen vascular plants species were identified from the soil seedbanks, while three additional species (members of the Fabaceae, Poaceae and Cyperaceae) remained unidentified (Additional file 1: Table S2). The majority were annuals (78\%) with only four perennial species (P. arundinacea, Lithospermum erythrorhizon, Potentilla supina and $C$. hederacea) detected. The soil seedbank composition was compared with the species composition of their corresponding perennial communities located at the higher part (mean $=185 \mathrm{~m}$ a.s.l.) and the annual communities at the lower part (mean $=169 \mathrm{~m}$ a.s.l.) of the drawdown zone (Table 2). The numbers of seeds and species detected in the combined annual and perennial communities were not significantly different. The similarity in species composition between the seedbank and above-ground vegetation was significantly lower in the perennial communities than in the annual communities.

The DCA of seedbank composition produced eigenvalues of $0.3306,0.2091$, and 0.1513 and gradient lengths of $3.515,2.724$, and 1.711 for the first three axes, respectively (Fig. 6). The site biplot showed a significant difference in the seedbank composition between the annual and perennial plant communities (PMAV, $F=4.92$, $r^{2}=0.15, P<0.01$; Fig. 6); the annual communities were located in the left side of the ordination and were correlated with annual species such as $P$. trigonocarpa, Cuscuta australis, P. nodosa, Mazus pulmilus. In contrast, the perennial communities were located at the positive end of Axis 1 and were correlated with perennial species such as C. hederacea, P. supina, P. arundinacea. Therefore, the structure of the soil seedbank changed along the vertical gradient of the drawdown zone.

\section{Discussion}

The drawdown zone vegetation is ecologically important as it provides a range of ecosystem services (Yuan et al. 2013); it stabilizes the shoreline, reduces erosion, improves water quality by trapping sediment and pollutants, and mitigates climate change by increasing the carbon sink. The communities also have intrinsic value on their own, providing food, cover, nesting, and sanctuary for animals, as well an esthetic quality that enhances cultural values and heritage. However, the drawdown zone is exposed to variable water level fluctuations, causing frequent stress events to flora. Our study is one of the first to investigate the concurrent effects of environmental changes along both the longitudinal and vertical gradients within the drawdown zone vegetation of monsoonal climates and link these effects to soil seedbank characteristics within a riverine reservoir. There have however been such large-scale studies on aquatic environments 

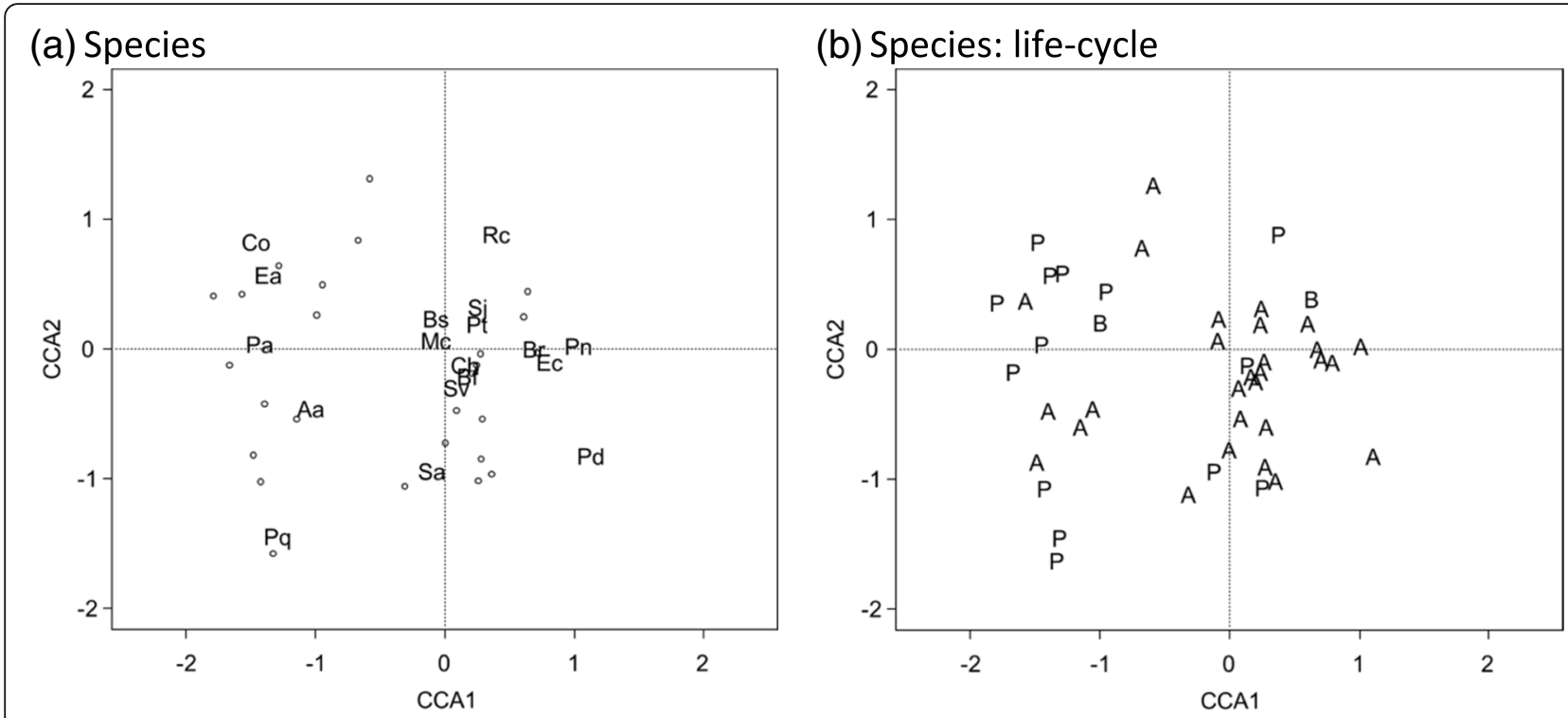

(c) Site

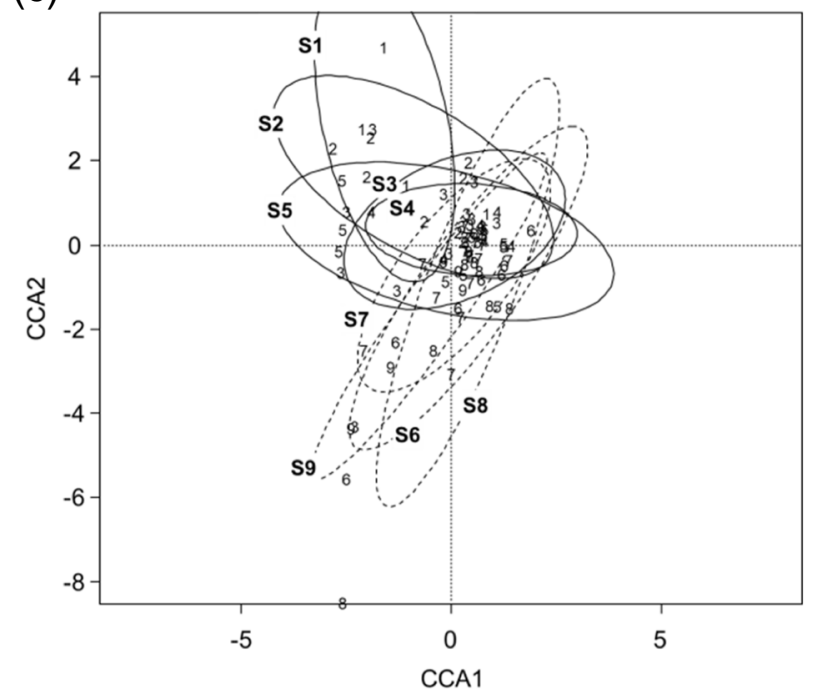

(d) Environmental factor

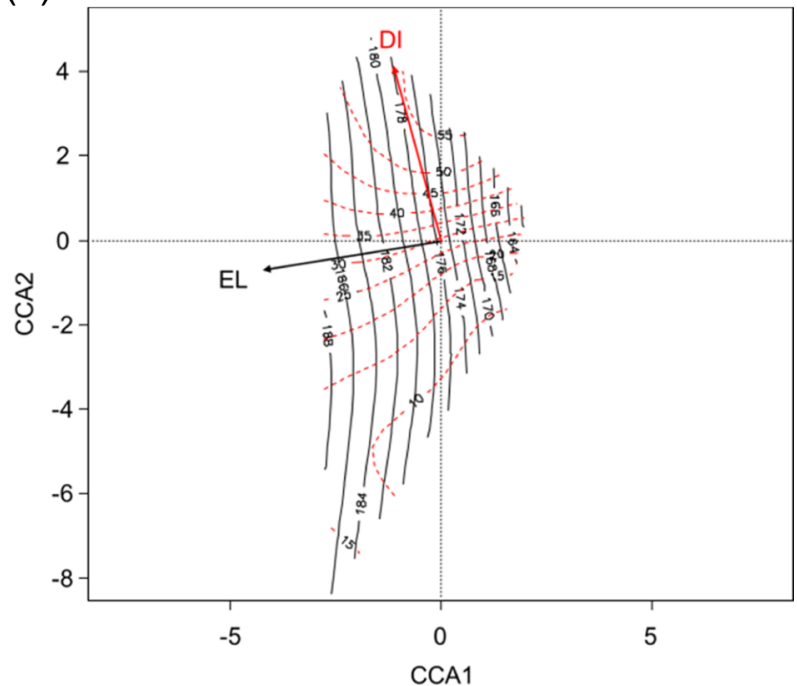

Fig. 4 Biplots from the canonical correspondence analysis (CCA) of the vegetation in the drawdown zone of the Soyangho Reservoir, South Korea. a Species plot (abbreviation, abundant species; open circle, less abundant species): Aa, Ambrosia artemisiifolia; Bf, Bidens frondosa; Br, Bidens radiata var. pinnatifida; Bs, Beckmannia syzigachne; Ch, Calystegia hederacea; Co, Carex orbicularis var. brachylepis; Ea, Equisetum arvense; Ec, Echinochloa crus-galli; Mc, Matricaria chamomilla; Pa, Phalaris arundinacea; $\mathrm{Pd}$, Panicum dichotomiflorum; Pn, Persicaria nodosa; Pq, Pteridium aquilinum var. latiusculum; Pt,

Persicaria trigonocarpa; Rc, Rumex crispus; Sa, Stellaria aquatica; Sj, Sagina japonica; and Sv, Setaria viridis. b Species plot by life-cycle (A, annuals; B, biennial; $P$, perennial). c Site plot along with 95\% confidence ellipses of the sampling sites (number relates to the sampling site in the Fig. 1), and (d) significant environmental variables at $p=0.05$ (EL, elevation; DI, distance from the dam; AN, slope angle) and isolines of elevation ( $\mathrm{m}$ above sea level, solid line) and distance from the dam ( $\mathrm{km}$, dotted line)

(Hu et al. 2018), fish (Vašek et al. 2004), and bacteria/plankton (Salcher et al. 2011). Our study site, the Soyangho Reservoir, provides an ideal place to investigate these two gradients because it has a long valley and wide water level fluctuations. Our results confirmed two main environmental gradients affecting the plant community structure within in a drawdown zone, the primary one along the vertical dimension from the water body to the higher elevations and a secondary one along the longitudinal dimension from the inflow to the dam.

The Soyangho Reservoir has dramatic changes in annual hydrological characteristics in order to prevent flooding of downstream urban areas; this is essential given the heavy seasonal rains that occur during the monsoonal period (Lauri et al. 2012; Bao et al. 2015). Just before the rainy season starts, the reservoir water 


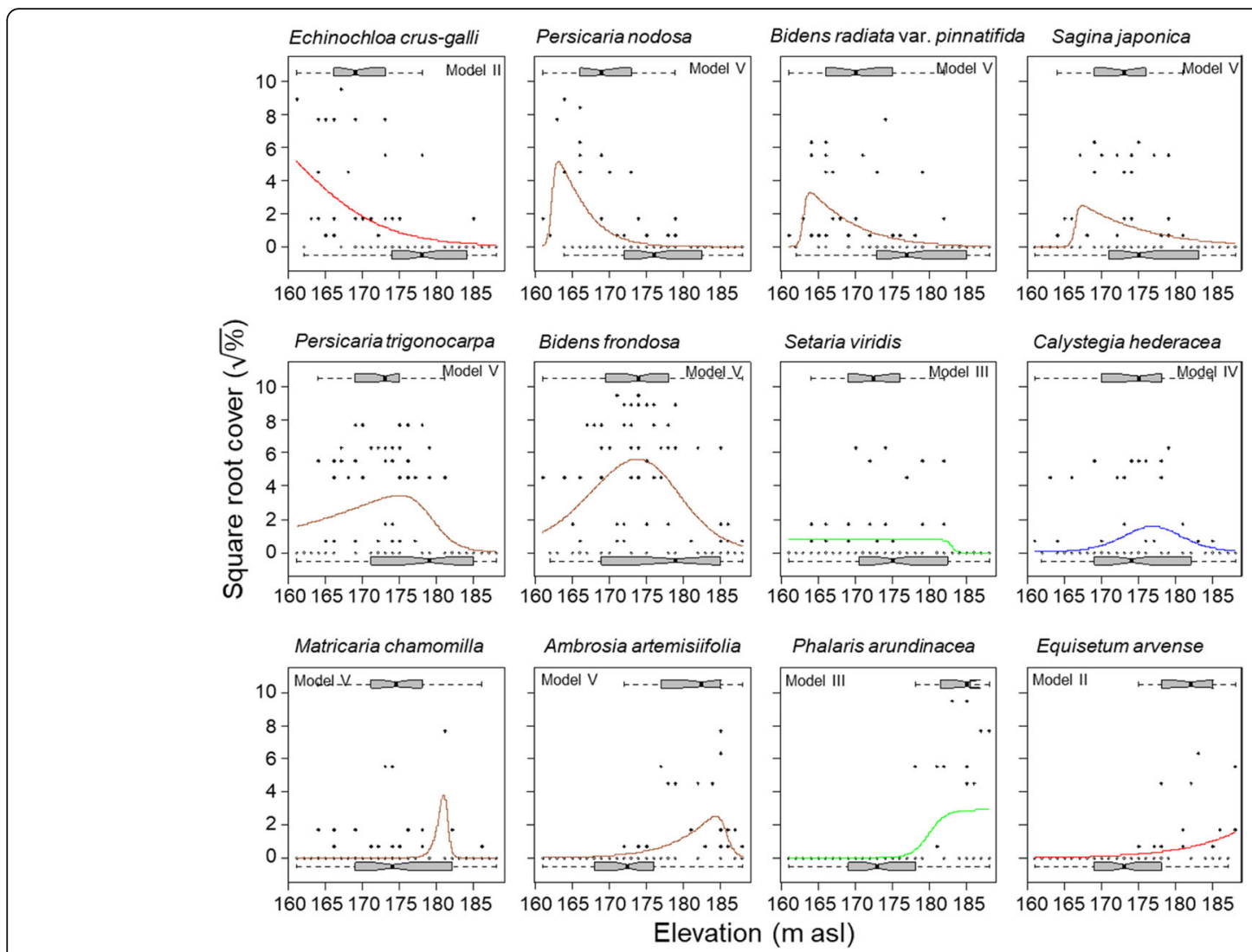

Fig. 5 Responses of the 12 most abundant species with respect to elevation in the drawdown zone of the Soyangho Reservoir, South Korea. These were derived from an extended Huisman-Olff-Fresco (eHOF) analysis of species cover data (square root transformed)

level is reduced to a minimum to secure their maximum potential storage capacity for the oncoming rains. After the rainy season is over, the water level is lowered continuously until the next flood season. Therefore, the vegetation in the drawdown zone is exposed to an annual flood/exposure cycle. Thus, within the reservoir where there is a wide annual water level fluctuation, the vertical gradient of water flood/exposure is a main factor in determining the plant distribution in the drawdown zone of reservoirs (Yuan et al. 2013), and that is in agreement with the results described in our work.

The second most important environmental gradient within the Soyangho Reservoir was the change along the longitudinal dimension from the river inflow to the dam. River damming causes fundamental change in river hydrology and morphology (Schmutz and Moog 2018). The functions and services provided by the aquatic ecosystems are changed by these alterations in flow regimes

Table 2 Comparisons of numbers of seeds of the main species detected in soil seedbanks from two plant community types, either dominated by annuals or perennials, within the drawdown zone of the Soyangho Reservoir, South Korea. The elevations of the sampled communities and the Sorensen Similarity Indices calculated between the composition of the seedbank and their respective plant communities presented

\begin{tabular}{|c|c|c|c|c|c|c|c|c|}
\hline \multirow[t]{3}{*}{ Soil seedbank } & \multicolumn{8}{|c|}{ Plant community } \\
\hline & \multicolumn{4}{|l|}{ Annual } & \multicolumn{4}{|l|}{ Perennial } \\
\hline & $\begin{array}{l}\text { Persicaria } \\
\text { trigonocarpa }\end{array}$ & $\begin{array}{l}\text { Bidens } \\
\text { frondosa }\end{array}$ & Persicaria nodosa & $\begin{array}{l}\text { Total } \\
(\text { mean } \pm \text { SE) }\end{array}$ & $\begin{array}{l}\text { Carex orbicularis } \\
\text { var. brachylepis }\end{array}$ & $\begin{array}{l}\text { Scirpus } \\
\text { radicans }\end{array}$ & $\begin{array}{l}\text { Phalaris } \\
\text { arundinacea }\end{array}$ & $\begin{array}{l}\text { Total } \\
(\text { mean } \pm \text { SE) }\end{array}$ \\
\hline No. of seeds $\left(\mathrm{m}^{-2}\right)$ & 68,917 & 6583 & 19,417 & $31,639 \pm 19,004^{a}$ & 10,750 & 24,833 & 7083 & $14,222 \pm 5410^{a}$ \\
\hline No. of species & 11 & 11 & 9 & $10.3 \pm 0.7^{\mathrm{a}}$ & 14 & 11 & 9 & $11.3 \pm 1.5^{\mathrm{a}}$ \\
\hline Sorensen Similarity (\%) & 50.0 & 28.6 & 31.6 & $36.7 \pm 6.7^{a}$ & 16.7 & 10.0 & 23.5 & $16.7 \pm 3.9^{b}$ \\
\hline Elevation ( $m$ a.s.l.) & 169 & 172 & 166 & $169.0 \pm 1.7^{\mathrm{a}}$ & 186 & 188 & 181 & $185.0 \pm 2.1^{b}$ \\
\hline
\end{tabular}

$\mathrm{a}, \mathrm{b}$ The different superscripts between values of the annual and perennial communities indicate the significant difference at $\alpha=0.05$ by $t$ test 


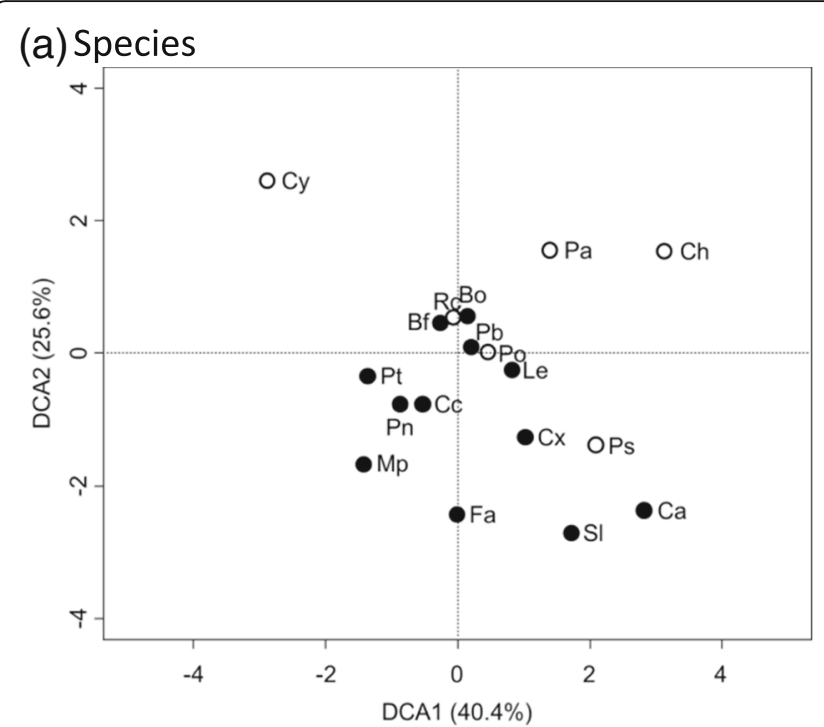

(b) Site

Fig. 6 Biplots from detrended correspondence analysis (DCA) of the seedbank in the drawdown zone of the Soyangho Reservoir, South Korea. a Species biplot (closed circle, annual species; open circle, perennial species): Bo, Barbarea orthoceras, Bf, Bidens frondosa; Ca, Chenopodium album var. centrorubrum; Cc, Conyza canadensis; Ch, Calystegia hederacea; Cx, Cuscuta australis; Cy, Cyperaceae sp.; Fa, Fabaceae sp.; Le, Lithospermum erythrorhizon; Mp, Mazus pumilus; Pa, Phalaris arundinacea; Pb, Panicum bisulcatum; Pn, Persicaria nodosa; Po, Poaceae sp.; Ps, Potentilla supina; Pt, Persicaria trigonocarpa; Rc, Rumex crispus; and SI, Stellaria alsine var. undulata. b Site biplot (closed circle and dashed ellipse, annual plant community; open circle and solid ellipse, perennial plant community): VBf, Bidens frondosa community; VCo, Carex orbicularis var. brachylepis community; VPa, Phalaris arundinacea community; VPn, Persicaria nodosa community; VPt, Persicaria trigonocarpa community; VSr, Scirpus radicans community. The ellipses illustrate 95\% confidence intervals

and morpho-dynamic patterns (Nilsson et al. 2005). Damming rivers then creates new lentic ecosystems that resemble lake-type systems, but as they are continuously disturbed through managed water level fluctuations and flooding, the reservoir ecosystems become hybrid systems that lose some lotic functions, but partly retain some lacustrine ones (Schmutz and Moog 2018). A longitudinal gradient may develop from upstream reaches (riverine zone) throughout middle stretches (transition zone) to the dam (lacustrine zone) depending on the size and shape of the reservoir (Kimmel and Groeger 1984). In the Soyangho Reservoir, which has one of the largest water surface area and the longest hydraulic residence time of about 9 months in Korea (Kim and Kim 2006), while lentic conditions prevail, fluvial characteristics are maintained to some extent along a longitudinal gradient. Like other flood control reservoirs in South Korea, the Soyangho Reservoir is located in the mountainous region upstream of rivers to reduce downstream flood disasters. The dendritic shape of the reservoir within deep canyons showed the clear geomorphological and related soil changes along the longitudinal gradient of $60 \mathrm{~km}$ long: the closer from the dam, the steeper the slope angle, the coarser the soil particle, and the drier the soil. The angle of the slope can impact on landslides, soil erosion, sedimentation, and soil moisture conditions in the drawdown zone (Yuan et al. 2013). The longitudinal gradient of soil properties due to geomorphological changes was another major factor in determining the plant distribution in the drawdown zone of the reservoir located in mountainous upstream area.

Our plant field survey results showed that plant community structure of the drawdown zone changed according to environmental changes along the vertical and longitudinal dimensions. The vertical gradient was most important, mainly because the water level fluctuates widely in the Soyangho Reservoir and the shoreline slopes are generally steep (Cho et al. 2018). We found that this gradient produced a change in plant communities from ephemeral annual-dominated communities at low water through to persistent perennial-dominated communities at the highest elevations (Cheon et al. 2010; Ye et al. 2013) . The period for which these species can grow is shortened as the height of the drawdown zone is lowered. On the other hand, the upper part of the drawdown zone which is usually connected to terrestrial forests and more stable communities of perennials can establish easily here because flooding duration of is very short and the disturbance by wave action is not severe. In any case, our results are in agreement with the descriptions of plant species segregation along a hydrological gradient in stream floodplains and reservoir shorelines (Schipper et al. 2011; Ye et al. 2013; Zhang et al. 2015).

The longitudinal gradient was also one of important factors in determining vegetation structure in the drawdown zone. At the site near the dam, bare land with almost no vegetation was widely-distributed on the steep slopes (Cho et al. 2018). Where the slope is steep, parent 
bedrock was exposed by soil erosion and vegetation colonization was low. At the more distant sites from the dam, plants adapted to drier or mesic conditions were found in the upper part of the drawdown zone close to upland forests. In the site furthest form the dam riverine, vegetation appeared on temporary bars due to the development of the fluvial environments. Our results showed, however, that changes in plant communities and plant species response were more pronounced along the vertical rather than the longitudinal dimension.

The final part of our study explores the spatial variation of the soil seedbank along the vertical dimension in the Soyangho Reservoir. The structure of soil seedbank and its relationship with the above-ground vegetation are considered a crucial evidence for the recruitment of plant community after disturbance (Capon and Brock 2006; Bossuyt and Honnay 2008; Zhang et al. 2017). The results of the soil seedling emergence experiment showed that most species were annual herbs that can adapt to the flood pattern in agreement with results described by Zhang et al. (2017); moreover, annuals were more numerous at the lower elevations with perennials at the higher elevations. The similarity of species composition between soil seedbank and above vegetation in the annual community of the lower part was greater than that for the perennial vegetation in the upper part of the drawdown zone. It is well known that the soil seedbank of annuals certainly plays a more important role in the regeneration of the plant community in frequently disturbed areas (Landman et al. 2007; Zhang et al. 2017). The composition of the seedbanks was separated along the vertical gradient of the drawdown zone, and hence may play an important role in vegetation regeneration after flood/exposure disturbance in the lower drawdown zone (Zhang et al. 2016).

High magnitude and frequency of water level fluctuations creates "dead zones" along the reservoir for the flood control under a monsoonal climate (Schmutz and Moog 2018). Where the drawdown zone lacks vegetation the water level fluctuation has the potential to cause many environmental problems including landslides, soil erosion, water pollution, biodiversity loss, carbon sink decrease, and other issues (Yuan et al. 2013). Maintaining vegetation cover helps prevent this. It is, therefore, important to gain a better understanding of which environmental factors influence the plant communities in the reservoir shorelines to assist in planning reservoir management. Understanding the vertical and longitudinal environmental gradients affecting shoreline plant community structure, and the role of soil seedbanks, helps us develop strategies to conserve and restore the vegetation within the drawdown zone reservoirs in monsoonal climates and provide insight into the effect of the ecological environment on reservoir shoreline ecosystems.

\section{Conclusions}

In this study, we could identify two major environmental factors affecting these plant communities and soil seedbank within the drawdown zone of the Soyangho Reservoir under a monsoonal climate. Two main environmental gradients affecting the plant community structure were vertical and longitudinal gradients. On the vertical dimension, a gradient of flood and exposure, the annualdominated community at the lower drawdown zone was changed to a perennial-dominated community at the highest elevation. On the longitudinal dimension from the dam to the upstream, plant species was changed from an upland forest-edge vegetation to a lowland riverine vegetation with the changes in slope degree, soil particle size, and soil moisture content. The structure of soil seedbanks was changed from annuals near the water edge to some perennials at higher elevations along the vertical gradient. These results suggested that the vertical and longitudinal environmental gradients affecting shoreline plant community structure and soil seedbanks in the reservoirs should be considered for conserving and restoring the drawdown zone of a monsoonal climate.

\section{Additional file}

\begin{abstract}
Additional file 1: Table S1. The scales used to describe (a) the plant communities and (b) the soil texture (Japanese Society of Pedology 1997) within the of the drawdown zone of the Reservoir Soyangho in South Korea. Table S2. Numbers of seedlings (seeds $\mathrm{m}^{-2}$ ) for each species germinated from soils collected from six plant communities in the drawdown zone of the Soyangho Reservoir, South Korea; mean values ( $\pm S E, n=6$ ) are presented. Figure S1. Photographs of the drawdown zone vegetation in the Soyangho Reservoir, South Korea. Figure S2. Responses of the 12 most abundant species with respect to distance from the Soyangho Reservoir dam, South Korea. These were derived from an extended Huisman-Olff-Fresco (eHOF)
\end{abstract} analysis of species cover data (square root transformed). (DOCX 1557 kb)

\section{Abbreviations}

a.s.l.: Above sea level; AIC: Akaike information criterion; CCA: Canonical correspondence analysis; DCA: Detrended correspondence analysis; GNSS: Global navigation satellite system; HOF model: Huisman-Olff-Fresco model; PCA: Principal component analysis; PMAV: Permutational multivariate analysis of variance

\section{Acknowledgement}

We thank Dr. Seung-Nam Jin of ECOnGEO in South Korea for help with the field work.

\section{Authors' contributions}

$\mathrm{HC}$ and $\mathrm{KHC}$ participated in the design of the study and conducted field work. $\mathrm{HC}$, JGA, RHM, and KHC analyzed and interpreted the data. $\mathrm{KHC}$ and RHM wrote the manuscript. All authors read and approved the final manuscript.

\section{Funding}

This work was supported by INHA UNIVERSITY Research Grant.

\section{Availability of data and materials}

The datasets generated during and/or analyzed during the current study are available from the corresponding author on reasonable request.

Ethics approval and consent to participate Not applicable. 


\section{Consent for publication}

Not applicable.

\section{Competing interests}

The authors declare that they have no competing interests.

\section{Author details}

'Department of Biological Sciences, Inha University, Incheon 22212, Republic of Korea. ${ }^{2}$ School of Environmental Sciences, University of Liverpool, Liverpool L69 3GP, UK. ${ }^{3}$ Department of Crop and Forest

Sciences_AGROTECNIO Center, Universitat de Lleida, 25198 Lleida, Spain

${ }^{4}$ ECOnGEO, Seogjeongro 62, Incheon 22170, Republic of Korea.

Received: 28 April 2019 Accepted: 4 June 2019

Published online: 26 June 2019

\section{References}

Abrahams C. The ecology and management of drawdown zones. Br Wildl. 2005;16: 395-402.

Bao Y, Gao P, He X. The water-level fluctuation zone of Three Gorges Reservoir-a unique geomorphological unit. Earth-Sci Rev. 2015;150:14-24.

Baxter RM. Environmental effects of dams and impoundments. Annu Rev Ecol Evol Syst. 1977:8:255-83.

Bossuyt B, Honnay O. Can the seed bank be used for ecological restoration? An overview of seed bank characteristics in European communities. J Veg Sci. 2008;19(6):875-84.

Capon SJ, Brock MA. Flooding, soil seed bank dynamics and vegetation resilience of a hydrologically variable desert floodplain. Freshw Biol. 2006;51(2):206-23.

Cheon KS, Kim KA, Seo WB, Jang JH, Yoo KO. Distributional characteristics of vascular plants and plants selection for revegetation in bare ground of lakeside in artificial lakes. J Korea Soc Environ Restor Tech. 2010;13(2):24-41 in Korean.

Cho H, Jin SN, Marrs RH, Cho K-H. Floristic composition and phytomass in the drawdown zone of the Soyangho reservoir, Korea. Ecol Resil Infrastruct. 2018;5:94-104.

Han River Flood Control Office. Water resources management information system. 2018. http://www.wamis.go.kr/. Assessed 30 Oct 2018.

Hill NM, Keddy PA, Wisheu IC. A hydrological model for predicting the effects of dams on the shoreline vegetation of lakes and reservoirs. Environ Manag. 1998;22:723-36.

Hu S, Xia J, Wu X, Wang Y, Xia F. Water environment variation in the Three Gorges tributary and its influencing factors on different scales. Water. 2018; 10(12):1831.

Huisman J, Olff H, Fresco LFM. A hierarchical set of models for species response analysis. J Veg Sci. 1993;4:37-46.

Jansen F, Oksanen J. Package. eHOF. 2017. https://cran.r-project.org/web/ packages/eHOF/eHOF.pdf. Assessed 20 Oct 2018.

Japanese Society of Pedology. Soil survey handbook. Tokyo: Hakubunkan; 1997. (in Japanese)

Kim B, Choi K, Kim C, Lee U-H, Kim Y-H. Effects of the summer monsoon on the distribution and loading of organic carbon in a deep reservoir, Lake Soyang, Korea. Water Res. 2000;34:3495-504.

Kim Y, Kim B. Application of a 2-dimensional water quality model (CE-QUAL-W2) to the turbidity interflow in a deep reservoir (Lake Soyang, Korea). Lake Reserv Manag. 2006;22:213-22.

Kim YJ, Lee OM. A study of low-temperature and mountain epilithic diatom community in mountain stream at the Han River system, Korea. J Eco Environ. 2017:41:28.

Kimmel BL, Groeger AW. Factors controlling primary production in lakes and reservoirs: a perspective. Lake Reserv Manag. 1984;1:277-81.

Korea Geographic Information Institute. Digital topographic map. Suwon: Korea Geographic Information Institute; 2010.

Korea Meteorological Administration. Weather information. 2018. http://www. weather.go.kr/. Assessed 30 Oct 2018.

Korea National Arboretum. Korean plant names index. 2017. http://www.nature. go.kr/ekbi/plant/clss/KBI_2001_010100.do. Assessed 30 Aug 2017.

Landman GB, Kolka RK, Sharitz RR. Soil seed bank analysis of planted and naturally revegetating thermally-disturbed riparian wetland forests. Wetlands. 2007;27(2):211-23.

Lauri H, Moel HD, Ward PJ, Räsänen TA, Keskinen M, Kummu MS. Future changes in Mekong River hydrology: impact of climate change and reservoir operation on discharge. Hydrol Earth Syst Sci. 2012;16:4603-19.
Lee H, Alday JG, Cho K-H, Lee EJ, Marrs RH. Effects of flooding on the seed bank and soil properties in a conservation area on the Han River, South Korea. Ecol Eng. 2014;70:102-13.

Magurran AE. Ecological diversity and its measurement. Princeton: Princeton University Press; 1988.

Nilsson C, Keddy PA. Predictability of change in shoreline vegetation in a hydroelectric reservoir, northern Sweden. Can J Fish Aquat Sci. 1988;45:1896-904.

Nilsson C, Reidy CA, Dynesius M, Revenga C. Fragmentation and flow regulation of the world's large river systems. Science. 2005;308:405-8.

Oksanen J. Multivariate analysis of ecological communities in R: vegan tutorial; 2015. https://doi.org/10.1016/0169-5347(88)90124-3.

Oksanen J, Blanchet FG, Kindt R, Legendre P, Minchin PR, O'Hara RB, Simpson GL, Solymos P, Stevens MHH, Wagner H. Package 'vegan': community ecology package. 2016. http://vegan.r-forge.r-project.org. Assessed 30 Oct 2018.

R Core Team. R: a language and environment for statistical computing. Vienna: R Foundation for Statistical Computing; 2017. https://www.R-project.org/ . Assessed 15 Nov 2017

Salcher MM, Pernthaler J, Frater N, Posch T. Vertical and longitudinal distribution patterns of different bacterioplankton populations in a canyon-shaped, deep prealpine lake. Limnol Oceanogr. 2011;56(6):2027-39.

Schipper AM, Lotterman K, Leuven RS, Ragas AM, de Kroon H, Hendriks AJ. Plant communities in relation to flooding and soil contamination in a lowland Rhine River floodplain. Environ Pollut. 2011;159(1):182-9.

Schmutz S, Moog O. Dams: ecological impacts and management. In: Schmutz S, Sendzimir J, editors. Riverine ecosystem management. Cham: Springer; 2018. p. 111-27.

Thornton KW. Perspectives on reservoir limnology. In: Thornton KW, Kimmel BL, Payne FE, editors. Reservoir limnology: ecological perspectives. New York: Wiley; 1990. p. 1-13.

Vašek M, Kubečka J, Peterka J, Čech M, Draštík V, Hladík M, Prchalová M, Frouzová J. Longitudinal and vertical spatial gradients in the distribution of fish within a canyon-shaped reservoir. Int Rev Hydrobiol. 2004;89(4):352-62.

Wetzel RG. Limnology: Lake and river ecosystems. San Diego: Academic; 2001.

Ye C, Zhang K, Deng Q, Zhang Q. Plant communities in relation to flooding and soil characteristics in the water level fluctuation zone of the Three Gorges Reservoir, China. Environ Sci Pollut R. 2013;20:1794-802.

Yuan XZ, Zhang YW, Liu H, Xiong S, Li B, Deng W. The littoral zone in the Three Gorges Reservoir, China: challenges and opportunities. Environ Sci Pollut R. 2013;20:7092-102.

Zhang M, Chen F, Chen S, Wang Y, Wang J. Effects of the seasonal flooding on riparian soil seed bank in the Three Gorges Reservoir Region: a case study in Shanmu River. SpringerPlus. 2016;5:492.

Zhang M, Chen F, Chen S, Xie Z, Huang Y, Liu Y. The soil seed bank of a rehabilitated draw-down zone and its similarity to standing vegetation in the Three Gorges Reservoir Area. Ecol Res. 2017;32:1011-21.

Zhang X, Liu X, Wang H. Effects of water level fluctuations on lakeshore vegetation of three subtropical floodplain lakes, China. Hydrobiologia. 2015; 747:43-52.

Zohary T, Ostrovsky I. Ecological impacts of excessive water level fluctuations in stratified freshwater lakes. Inland Waters. 2011;1(1):47-59.

\section{Publisher's Note}

Springer Nature remains neutral with regard to jurisdictional claims in published maps and institutional affiliations.

Ready to submit your research? Choose BMC and benefit from:

- fast, convenient online submission

- thorough peer review by experienced researchers in your field

- rapid publication on acceptance

- support for research data, including large and complex data types

- gold Open Access which fosters wider collaboration and increased citations

- maximum visibility for your research: over $100 \mathrm{M}$ website views per year

At BMC, research is always in progress.

Learn more biomedcentral.com/submissions 